\title{
KAJIAN METODA PELAKSANAAN PEKERJAAN PONDASI BORED PILE PADA TAHAP PERENCANAAN PELAKSANAAN
}

\author{
I Wayan Jawat ${ }^{1}$, Putu Panji Tresna Gita ${ }^{1)}$, dan I Made Satria Dharmayoga ${ }^{1)}$ \\ 1) Program Studi Teknik Sipil Universitas Warmadewa, Denpasar, Bali \\ jawatiwayan76@gmail.com
}

\begin{abstract}
Bored pile foundation is a pile foundation whose installation is done by drilling the soil first. This type of bored pile foundation is widely used in construction projects. The selected bore pile foundation is adjusted to the type of soil, terrain conditions, and the selected construction method. The construction method is the elaboration of procedures and works implementation techniques which are the core of all activities in the construction management system. For this reason, it is interesting to study the method of implementing the bore pile foundation at the planning stage of the implementation of the GOR Development project in Abiansemal, Badung. The implementation planning stage is an important activity in order to provide a more detailed picture of strategies and techniques for working efficiently and effectively in terms of time, quality and cost. The goal to be achieved in this research is to study the method of implementing the foundation at the planning stage of implementation. So that it can contribute to the development of knowledge about the application of the theory of the method of implementing the bore pile foundation and is information for those who are interested in further research. Based on the results of the study that the preparatory work begins with the determination of the pile center point and placement of bored pile devices. In drilling work using the wet drilling method volume $1105.00 \mathrm{~m}$ with a duration of 8 days. For the work of reinforcing the volume of $9309.61 \mathrm{~kg}$ and the duration of 13 days was preceded by the fabrication process and continued with the installation of reinforcement into the borehole. Casting is done using a pipe, volume $74.394 \mathrm{~m}^{3}$ with a duration of 11 days. Next, determine the pile cap and excavation work, followed by pile cap floor work with concrete fillings, volume $136.708 \mathrm{~m}^{3}$ for 6 days. As formwork using concrete blocks with a volume of $237.474 \mathrm{~m}^{2}$ worked on for 14 days, followed by the formation of reinforcement and assembly of volume $5454.21 \mathrm{~kg}$ with a duration of 9 days and casting methods carried out manually with a volume of $117.632 \mathrm{~m}^{3}$ and a duration of 14 days.
\end{abstract}

Keywords: bored pile foundation, construction method, planning of implementation 


\begin{abstract}
ABSTRAK
Pondasi bored pile adalah pondasi tiang yang pemasangannya dilakukan dengan mengebor tanah lebih dahulu. Jenis pondasi bored pile banyak digunakan pada proyek konstruksi. Pelaksanaan pondasi bored pile yang dipilih disesuaikan dengan jenis tanah, kondisi medan serta metode konstruksi yang terpilih. Metode konstruksi merupakan penjabaran tata cara dan teknik-teknik pelaksanaan pekerjaan yang merupakan inti dari seluruh kegiatan dalam sistem manajemen konstruksi. Untuk itu menarik dilakukan kajian bagaimanakah metode pelaksanaan pondasi bored pile pada tahap perencanaan pelaksanaan pada proyek Pembangunan GOR di Abiansemal,Badung. Tahap perencanaan pelaksanaan merupakan kegiatan yang penting guna memberikan gambaran lebih rinci tentang strategi dan teknik pengerjaan secara efisien dan efektip baik dari segi waktu,mutu dan biaya. Adapun tujuan yang ingin dicapai dalam penelitian ini adalah melakukan kajian mengenai metode pelaksanaan pondasi pada tahap perencanaan pelaksanaan. Sehingga dapat memberikan sumbangan dalam pengembangan ilmu pengetahuan tentang penerapan teori metode pelaksanaan pondasi bored pile dan merupakan informasi bagi mereka yang tertarik dengan penelitian selanjutnya. Berdasarkan hasil kajian bahwa pada pekerjaan persiapan diawali dengan penentuan titik pusat pile dan penempatan alat bored pile. Pada pekerjaan pengeboran menggunakan metode wet drilling volume $1105 \mathrm{~m}$ dengan durasi 8 hari. Untuk pekerjaan pembesian volume $9309.61 \mathrm{~kg}$ dan durasi 13 hari didahului dengan proses fabrikasi dan dilanjutkan dengan pemasangan tulangan ke dalam lubang bor. Pengecoran dilakukan menggunakan pipa tremi, volume $74.394 \mathrm{~m}^{3}$ dengan durasi 11 hari. Selanjutnya dilakukan penentuan as pile cap dan pekerjaan galian,dilanjutkan dengan pekerjaan lantai pile cap dengan pasir urugan beton, volume $136.708 \mathrm{~m}^{3}$ selama 6 hari. Sebagai bekisting menggunakan batako dengan volume 237.474 $m^{2}$ dikerjakan selama 14 hari, dilanjutkan dengan pembentukan tulangan dan perakitan tulangan volume $5454.21 \mathrm{~kg}$ dengan durasi 9 hari serta metode pengecoran dilakukan dengan cara manual dengan volume $117.632 \mathrm{~m}^{3}$ dan durasi 14 hari.
\end{abstract}

Kata kunci: pondasi bored pile, metode konstruksi, perencanaan pelaksanaan 


\section{PENDAHULUAN}

\subsection{Latar Belakang}

Sebuah proyek adalah usaha yang komplek,tidak rutin yang dibatasi oleh waktu,anggaran, sumber daya, dan spesifikasi kinerja yang dirancang untuk memenuhi kebutuhan pelanggan (W.Lar, 2006). Proyek konstruksi merupakan suatu rangkaian kegiatan yang saling berkaitan untuk mencapai tujuan tertentu(bangunan/konstruksi) dalam batasan waktu, biaya dan mutu tertentu. Proyek konstruksi selalu memerlukan resources (sumber daya) yaitu man (manusia), material (bahan bangunan), machine (peralatan), method (metode pelaksanaan), money (uang), information (informasi), dan time (waktu).

Metode konstruksi adalah penjabaran tata cara dan teknik-teknik pelaksanaan pekerjaan yang merupakan inti dari seluruh kegiatan dalam sistem manajemen konstruksi. Metode juga merupakan kunci untuk dapat mewujudkan seluruh perencanaan menjadi bentuk bangunan fisik (Dipohusodo, 1996). Dalam pelaksanaan pembangunan yang menerapkan metode konstruksi dengan inovasi teknologi, meliputi rangkaian kegiatan dan urutan kegiatan pembangunan yang dipadukan dengan persyaratan kontrak (gambar, spesifikasi, jadwal penyelesaian), ketersediaan sumberdaya (tenaga kerja, material, peralatan) dan kondisi lingkungan seperti cuaca, kondisi tanah, dan lainnya.

Jenis pondasi bored pile banyak digunakan pada proyek konstruksi,demikian pula pada proyek Pembangunan GOR di Abiansemal Badung. Sebagaimana diketahui pondasi bored pile adalah pondasi tiang yang pemasangannya dilakukan dengan mengebor tanah lebih dahulu.

Beberapa penelitian tentang bored pile telah banyak dilakukan, diantaranya oleh Mubarak, Bulba, \& Yunita (2014) melakukan kajian mengenai besaran produktivitas pekerjaan pondasi bored pile. Hasil kajiannya mendapatkan nilai produktivitas pekerjaan pondasi bored pile sebesar $3.14 \mathrm{~m}^{3} / \mathrm{jam}$. Fadilah \& Tunafiah (2018) mengkaji tentang daya dukung pondasi bored pile berdasarkan data $\mathrm{N}$ SPT menurut rumus Reese \& Wright dan penurunan. Sementara itu Dhiva (2014) melakukan kajian mengenai faktor-faktor yang mempengaruhi produktivitas pengeboran bored pile dengan menggunakan mesin bor ringan metode direct wash dan pengaruhnya terhadap produktivitas pengeboran. Livia \& Suhendra (2018) melakukan studi kapasitas tiang bor berdasarkan metode 
pile driving analyzer (PDA) dan load cell, menyatakan terdapat perbedaan antara hasil dukung dari perhitungan manual dengan hasil daya dukung dari PDA dan/atau load cell.

Berdasarkan studi yang telah dilakukan tersebut baik mengenai analisis yang gunakan dengan berbagai metode maupun perhitungan produktivitas pondasi bored pile. Maka menjadi menarik untuk dilakukan kajian bagaimanakah metode pelaksanaan pondasi bored pile pada tahap perencanaan pelaksanaan pada proyek Pembangunan GOR di Abiansemal Badung.

\subsection{Permasalahan Penelitian}

Dari latar belakang tersebut, maka permasalahan yang peneliti angkat dalam penelitian ini adalah bagaimanakah metode pelaksanaan pondasi bored pile?

\subsection{Tujuan Penelitian}

Tujuan yang ingin dicapai dalam penelitian ini adalah mengkaji metode pelaksanaan pondasi pada tahap perencanaan pelaksanaan.

\subsection{Manfaat Penelitian}

\subsubsection{Manfaat teoritis}

1. Meningkatkan

pemahaman tentang penerapan teori metode pelaksanaan pondasi bored pile pada tahap perencanaan.
2. Sebagai sumbangan dalam pengembangan ilmu pengetahuan tentang penerapan teori metode pelaksanaan pondasi bored pile dan merupakan informasi bagi mereka yang tertarik dengan penelitian selanjutnya.

\subsubsection{Manfaat praktis}

1. Sebagai sumbangan pemikiran bagi institusi pendidikan dalam mengembangkan dan menerapkan pengetahuan tentang metode pelaksanaan pondasi bored pile.

2. Memberikan masukan terhadap hasil kajian yang dilakukan sebagai upaya peningkatan pemahaman manajerial dalam dunia konstruksi bagi kontraktor, konsultan dan masyarakat umum dalam pengelolaan metode pelaksanaan pondasi bored pile pada tahap perencanaan pelaksanaan, sehingga mampu meningkatkan keunggulan kompetitif.

\section{KAJIAN PUSTAKA}

\subsection{Pengertian pondasi}

Pondasi adalah bagian terendah dari bangunan yang meneruskan beban 
bangunan ke tanah atau batuan yang ada di bawahnya.Terdapat dua klasifikasi pondasi, yaitu pondasi dangkal dan pondasi dalam. Pondasi dangkal didefinisikan sebagai pondasi yang mendukung bebannya secara langsung, seperti: pondasi telapak, pondasi memanjang dan pondasi rakit. Pondasi dapat didefinisikan sebagai pondasi yang meneruskan beban bangunan ke tanah keras atau batuan yang terletak relatif jauh dari permukaan, contohnya pondasi sumuran dan pondasi tiang (Hardiyatmo, 2011).

\subsection{Pondasi Bored Pile}

Pemilihan jenis pondasi bergantung pada beban yang harus didukung, kondisi tanah pondasi dan biaya pembuatan pondasi yang dibandingan terhadap biaya struktur atasnya (Hardiyatmo, 2011). Pemasangan pondasi bored pile ke dalam tanah dilakukan dengan cara mengebor tanah terlebih dahulu, yang kemudian diisi tulangan yang telah dirangkai dan dicor beton. Apabila tanah mengandung air, maka dibutuhkan pipa besi atau yang biasa disebut dengan temporary casing untuk menahan dinding lubang agar tidak terjadi kelongsoran, dan pipa ini akan dikeluarkan pada waktu pengecoran beton
Ada beberapa keuntungan dalam pemakaian pondasi bored pile jika dibandingkan dengan tiang pancang, yaitu:

1. Pemasangan tidak menimbulkan gangguan suara dan getaran yang membahayakan bangunan sekitarnya.

2. Mengurangi kebutuhan beton dan tulangan dowel pada pelat penutup tiang (pile cap). Kolom dapat secara langsung diletakkan di puncak bored pile.

3. Kedalaman tiang dapat divariasikan.

4. Tanah dapat diperiksa dan dicocokkan dengan data laboratorium.

5. Bored pile dapat dipasang menembus batuan, sedang tiang pancang akan kesulitan bila pemancangan menembus lapisan batuan.

6. Diameter tiang memungkinkan dibuat besar, bila perlu ujung bawah tiang dapat dibuat lebih besar guna mempertinggi kapasitas dukungnya.

7. Tidak ada risiko kenaikan muka tanah.

Kerugian menggunakan pondasi bored pile, yaitu: 
1. Pengecoran bored pile dipengaruhi kondisi cuaca.

2. Pengecoran beton agak sulit bila dipengaruhi air tanah karena mutu beton tidak dapat dikontrol dengan baik.

3. Mutu beton hasil pengecoran bila tidak terjamin keseragamannya di sepanjang badan bored pile mengurangi kapasitas dukung bored pile, terutama bila bored pile cukup dalam.

4. Pengeboran dapat mengakibatkan gangguan kepadatan, bila tanah berupa pasir atau tanah yang berkerikil.

5. Air yang mengalir ke dalam lubang bor dapat mengakibatkan gangguan tanah, sehingga mengurangi kapasitas dukung tiang.

6. Akan terjadi tanah runtuh jika tindakan pencegahan tidak dilakukan, maka dipasang temporary casing untuk mencegah terjadinya kelongsoran.

\subsection{Metode konstruksi.}

Metode konstruksi adalah suatu perencanaan yang memberikan gambaran bagaimana cara melaksanakan suatu pekerjaan, baik sacara global maupun tiap kegiatan (Asiyanto, 2010). Metode konstruksi juga dapat diartikan penjabaran tata cara dan teknik-teknik pelaksanaan pekerjaan yang merupakan inti dari seluruh kegiatan dalam sistem manajemen konstruksi. Metode juga merupakan kunci untuk dapat mewujudkan seluruh perencanaan menjadi bentuk bangunan fisik (Dipohusodo, 1996). Penerapan konsep rekayasa berpijak pada keterkaitan antara persyaratan dalam dokumen pelelangan (dokumen pengadaan), keadaan teknis dan ekonomis yang ada dilapangan, dan seluruh sumber daya termasuk pengalaman kontraktor.

Metode pelaksanaan pekerjaan merupakan urutan pelaksanaan pekerjaan yang logis dan teknik sehubungan dengan tersedianya sumber daya yang dibutuhkan dan kondisi medan kerja, guna memperoleh cara pelaksanaan yang efektif dan efisien. Metode pelaksanaan pekerjaan yang ditampilkan dan diterapkan merupakan cerminan dari profesionalitas sang pelaksana proyek tersebut, atau profesionalitas dari tim pelaksana proyek, yaitu manajer proyek dan perusahaan yang bersangkutan. Metode konstruksi untuk pekerjaan besar terkadang menjadi persyaratan penting dalam proses klarifikasi proyek. Metode konstruksi 
haruslah dikembangkan dalam upaya mencapai peningkatan efisiensi dan kemudahan pelaksanaan serta memberikan alternatif yang dapat dilakukan namun secara detail tidak dapat distandarkan (Asiyanto, 2010).

\subsection{Penentuan Metode Pelaksanaan Pekerjaan.}

Tahap pertama sebelum memulai suatu pelaksanaan proyek konstruksi, harus ditentukan terlebih dahulu suatu metode untuk melaksanakannya. Dalam skala organisasi suatu proses perencanaan pelaksanaan proyek konstruksi, sangatlah penting untuk menentukan metode konstruksi terlebih dahulu, karena setiap jenis metode konstruksi akan memberikan karakteristik pekerjaan berbeda. Penentuan jenis metode konstruksi yang dipilih akan sangat membantu menentukan jadwal proyek. Menentukan metode konstruksi yang tepat dalam suatu proses produksi. Menyempurnakan penggunaan metode pelaksanaan dengan cara mengeliminasi kegiatan yang tidak diperlukan, mengoptimalkan penggunaan pekerja, alat dan material. Meningkatkan produktivitas dari suatu kegiatan.Setiap metode yang dipilih untuk digunakan dalam melaksanakan proyek konstruksi harus diyakinkan mengenai manfaat dan efisiensinya (Ervianto, 2005).
Metode konstruksi yang berbeda akan memberikan ruang lingkup pekerjaan dan durasi yang berbeda pula, yang sudah barang tentu juga mempunyai pertimbangan finansial dalam bentuk biaya. Ada faktor-faktor yang mempengaruhi jenis ruang lingkup pekerjaan yang dilakukan, sehingga perlu diperhatikan dan dipertimbangkan, yaitu:

1. Sumber daya manusia dengan skill yang cukup untuk melaksanakan suatu metode pelaksanaan konstruksi.

2. Tersedianya peralatan penunjang pelaksanaan metode konstruksi yang dipilih.

3. Material cukup tersedia.

4. Waktu pelaksanaan yang maksimum dibanding pilihan metode konstruksi lainnya.

5. Biaya yang bersaing.

Oleh karena faktor-faktor yang mempengaruhi metode pelaksanaan seperti: design bangunan, medan/lokasi pekerjaan, dan ketersediaan dari tenaga kerja, bahan, dan peralatan, seperti sudah dijelaskan diatas, maka kadang-kadang metode pelaksanaan hanya memiliki alternatif yang terbatas. 


\subsection{Dokumen Metode}

Dokumen yang mendukung dalam metode pelaksanaan proyek:

1. Gambar perencanaan

Gambar perencanaan adalah gambar yang dihasilkan dari pemikiran para perencana seperti arsitek, engineer struktur, mekanikal dan elektrikal. Gambar perencanaan merupakan visualisasi ide dari para perencana yang digunakan sebagai alat komunikasi kepada owner, untuk dapat memenuhi kebutuhan dan keinginan owner. Dalam hal ini gambar perencanaan seringkali mengalami banyak perubahan hingga sampai pada tahap yang disepakati bersama. Namun gambar ini, menjadi arah yang jelas untuk membuat gambar tender, yang lebih detail dan teknis, sebagai acuan pada tahap tender. Karena itu dalam penilaian untuk menentukan pemenang tender, penyajian metode pelaksanaan pekerjaan mempunyai 'bobot' peniliaian yang tinggi. Yang diperhatikan bukan rendahnya nilai penawaran harga, meskipun kita akui bahwa rendahnya nilai penawaran merupakan jalan untuk memperoleh peluang ditunjuk menjadi pemenang tender/pelelangan (Syah, 2004).
2. Gambar bantu

Gambar bantu yang dimaksud merupakan gambar-gambar detail yang menjelaskan lebih rinci mengenai desain yang dimaksud. Skala yang digunakan pun seringkali skala-skala yang besar, tebal tipis garis sangat membantu menjelaskan bentuk desainnya dan membuat gambar lebih rapi dan bisa dibaca dengan baik, dan juga bentuk tulisan, penempatannya dan rujukannya.

3. Uraian pelaksanaan pekerjaan.

4. Perhitungan kebutuhan sumber daya.

5. Jadwal kebutuhan sumber daya.

6. Dokumen lainnya.

\section{METODE PENELITIAN}

\subsection{Sumber dan Jenis Data}

Data yang didapat bersumber dari CV. Artha Pratama. Jenis data yang diperoleh adalah:

1. Spesifikasi umum.

2. Spesifikasi teknis.

3. Gambar perencanaan.

4. Uraian pekerjaan pondasi atau scope pekerjaan pondasi dapat dilihat pada Tabel 1 di bawah ini: 
Tabel 1. Scope Pekerjaan Pondasi

\begin{tabular}{cl}
\hline No & \multicolumn{1}{c}{ Uraian pekerjaan } \\
\hline 1 & Pekerjaan persiapan \\
2 & Pekerjaan pengeboran bored pile \\
3 & Pekerjaan pembesian bored pile \\
4 & Pekerjaan pengecoran bored pile \\
5 & Pekerjaan galian tanah pile cap \\
6 & Pekerjaan bekisting pile cap \\
7 & Pekerjaan pembesian pile cap \\
8 & Pekerjaan pengecoran pile cap \\
9 & Pekerjaan urugan pile cap \\
\hline
\end{tabular}

\subsection{Instrumen Penelitian}

Instrumen penelitian digunakan untuk mengukur nilai variabel yang diteliti. Instrumen-instrumen ini dapat dijadikan dasar dalam proses penelitian ini. Untuk mengetahui instrumen, maka perlu diketahui dahulu permasalah-permasalahan yang muncul berkaitan dengan teknis pelaksanaan pekerjaan. Instrumen pendukung diperlukan untuk memberikan gambaran lebih detail sebelum proses pelaksanaan pekerjaan di lapangan. Penyusunan instrumen teknis pelaksanan pekerjaan diperlukan untuk mengetahui metode yang digunakan sesuai dengan kondisi medan di lapangan termasuk pemilihan jenis peralatan yang dipakai. Instrumen yang dimaksud list mengenai: jenis alat, type/kapasitas alat, ketersediaan sdm, spesifikasi teknis pekerjaan serta kondisi medan di lokasi proyek menjadi indikator yang perlu dipertimbangkan dalam penerapan metode yang tepat.
Diharapkan dengan dilakukan penelitian ini dapat memberikan gambaran secara menyeluruh tentang permasalahan mengenai metode pada pelaksanaan pekerjaan pondasi bored pile dan dapat ditemukan solusi dari permasalahan tersebut.

\subsection{Metode Pengambilan Data}

Dalam metode pengambilan data untuk menerapkan metode pelaksanaan pekerjaan ini, digunakan beberapa cara yaitu:

1. Metode wawancara

Metode wawancara ini dilakukan dengan cara menanyakan informasi mengenai spesifikasi proyek dan gambaran umum proyek.

2. Metode studi pustaka

Metode studi pustaka ini dilakukan dengan mencari literatur yang berkaitan dengan topik yang diangkat atau dibahas didalam penelitian ini.

3. Metode observasi

Metode observasi dilakukan dengan cara pengamatan survey langsung ke lapangan.

\subsection{Metode Analisis Data}

Dalam menganalisa data yang ada diperlukan metode analisis yaitu suatu cara atau metode yang dipakai untuk 
menganalisa data dengan berpedoman pada pustaka yang ada, untuk memperoleh solusi dari tujuan penelitian.

\subsection{Prosedur Penelitian}

Untuk memperlancar kegiatan penelitian, tahapan yang dilaksanakan sebagai berikut:

1. Pengumpulan data dasar penelitian dilakukan dengan survey wawancara mendalam dan mengambil dokumen data yang telah ada sebagai pendukung awal.

2. Data dari lapangan kemudian diolah dalam bentuk kajian sistematis yang saling berkait dan untuk selanjutnya dipakai sebagai dasar analisis.

3. Berdasarkan telaah metode dari studi pustaka selanjutnya dilakukan analisis data. Hasil dari analisis data tersebut dipakai sebagai dasar dalam analisis penerapan metode terpilih dan pembuatan simpulan, selanjutnya diberikan saran-saran bila dianggap perlu.

Untuk dapat lebih mengarahkan pada jalannya penelitian dan dapat menghasilkan hasil penelitian yang cermat dan teliti, maka dibutuhkan adanya prosedur penelitian sebagai pedoman dalam pelaksanaannya (Jawat, Rahadiani, \& Armaeni, 2018).

\section{HASIL DAN PEMBAHASAN}

\subsection{Metode Pekerjaan Pondasi Bored Pile}

Tahapan pelaksanaan pondasi bored pile dapat digambarkan dalam flow chart sebagai berikut:

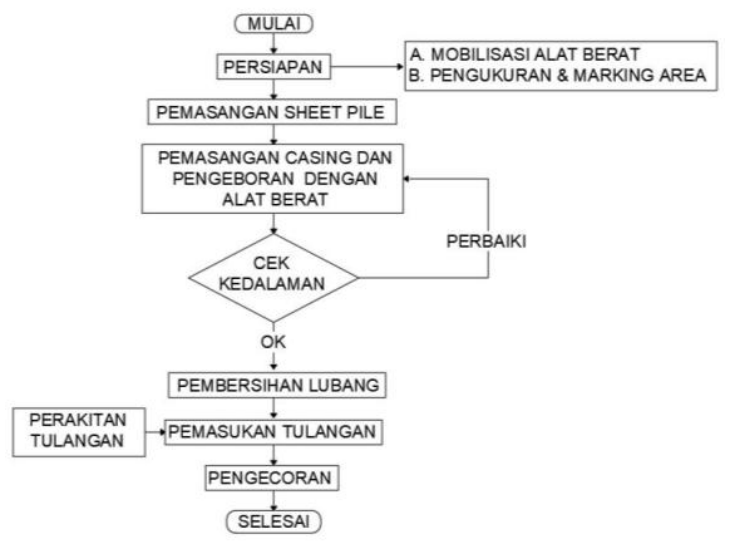

Gambar 1. Flowchart Pekerjaan Pondasi Bored Pile

\subsubsection{Pekerjaan persiapan}

Dari hasil kajian didapat komposisi sumber daya pekerjaan persiapan sebagai berikut:

Tabel 1. Komposisi Sumber Daya Pekerjaan Persiapan

\begin{tabular}{ccc}
\hline Tenaga kerja & Alat & Bahan \\
\hline 3 orang & 1 buah & cat pilox \\
pekerja & meteran & \\
1 orang & 1 unit & \\
mandor & theodolit & \\
2 orang & & \\
surveyor & & \\
\hline
\end{tabular}


Sebelum melakukan pengeboran pondasi bored pile, hal yang dilakukan adalah pekerjaan persiapan, meliputi:

1. Penentuan titik pusat pile

Titik pusat dari pile di survey dan di tandai dengan angker baja. Penentuan titik lubang bor setiap saat harus dilakukan pengecekan berulang kali karena kondisi lahan yang rusak akibat pengeboran. Penempatan alat bor pada posisi yang telah ditentukan, kemudian dilakukan pengecekan posisi vertikal dan horizontal, seperti Gambar 2.

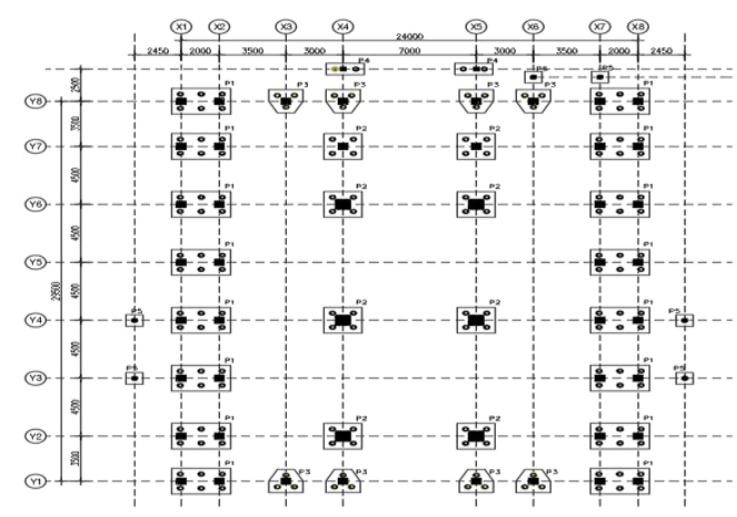

Gambar 2. Penentuan Titik Pondasi (Sumber: Anonim, 2018)

2. Pemasangan dan penempatan alat bor

Setelah alat bored pile masuk lokasi kerja, langkah awal yaitu merakit alat dan membuat bak sirkulasi (jika dibutuhkan). Untuk penempatan alat bor dilapangan, digunakan plat-plat baja sebagai tempat mesin bor dan pondasi minicrane untuk menstabilkan kondisi tanah akibat pengecoran apabila kondisi tanah dasar rusak oleh lumpur.

\subsubsection{Pekerjaan pengeboran bored pile}

Volume pekerjaan adalah $1105.00 \mathrm{~m}$, dengan durasi selama 8 hari. Komposisi sumber daya pekerjaan pengeboran bored pile dapat dilihat pada tabel di bawah ini:

Tabel 2. Komposisi Sumber Daya Pekerjaan Pengeboran

\begin{tabular}{ccc}
\hline Tenaga kerja & Alat & Bahan \\
\hline 4 orang & 1 unit mini & 16.796 liter \\
pekerja & crane & air \\
1 orang & 1 unit mata \\
mandor & bor cross bit \\
& 1 unit Pompa \\
& N880 \\
\hline
\end{tabular}

Pengeboran menggunakan metode wet drilling. Tanah dikikis dengan menggunakan mata bor cross bit pengikisan tanah dibantu dengan tiupan air lewat lubang stang bor yang dihasilkan pompa NS80, Hal ini menyebabkan tanah yang terkikis terdorong keluar dari lubang bor.

Setelah mencapai kedalaman rencana, pengeboran dihentikan, sementara mata bor dibiarkan berputar tetapi beban penekanan dihentikan dan air sirkulasi tetap berlangsung terus sampai cutting atau serpihan tanah betul-betul terangkat seluruhnya. Selama pembersihan ini berlangsung, besi tulangan dan pipa tremi 
sudah disiapkan di dekat lubang bor. Setelah cukup bersih, stang bor diangkat dari lubang bor, dengan bersihnya lubang bor diharapkan pengecoran akan baik hasilnya.

\subsubsection{Metode pekerjaan pembesian bored pile \\ Sebelum pekerjaan pemasangan} tulangan bored pile ke dalam lubang bor harus diparalelkan dengan pekerjaan pembuatan/perakitan tulangan bored pile. Metode saat perakitan tulangan baja (pembesian) dipilih dengan metode konvensional dengan langkah-langkah sebagai berikut:

1. Pembuatan besi spiral

Volume pekerjaan sebesar $9309.61 \mathrm{~kg}$, dengan durasi selama 13 hari. Komposisi sumber daya pekerjaan pembesian dapat dilihat pada tabel di bawah ini:

Tabel 3. Komposisi Sumber Daya Pekerjaan Pembesian

\begin{tabular}{ccc}
\hline Tenaga kerja & Alat & Bahan \\
\hline 24 or.pekerja & 1 unit mesin & $9309.61 \mathrm{~kg}$ \\
2 or.mandor & cutting bar & besi \\
3 or.kepala & 1 unit & $399 \mathrm{~kg}$ \\
tukang besi & penggulung & kawat \\
24 or.tukang & besi & bendrat \\
las & 1 unit mini \\
konstruksi & crane \\
& 1 bh.meteran \\
\hline
\end{tabular}

Pada pembuatan tulangan besi spiral pembengkokan menggunakan cara manual. Berikut merupakan syarat dari gambar kerja yang sudah tersedia:

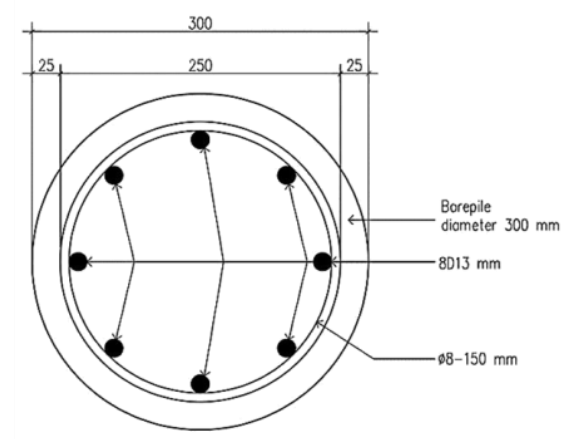

Gambar 3. Detail Pembesian (Sumber: Anonim, 2018)

Pada bagian ini hanya terdapat 1 segmen. Segmen dengan ukuran lingkaran adalah $30 \mathrm{~cm}$, jarak spiral $15 \mathrm{~cm}$ dan menggunakan besi berdiameter $8 \mathrm{~mm}$

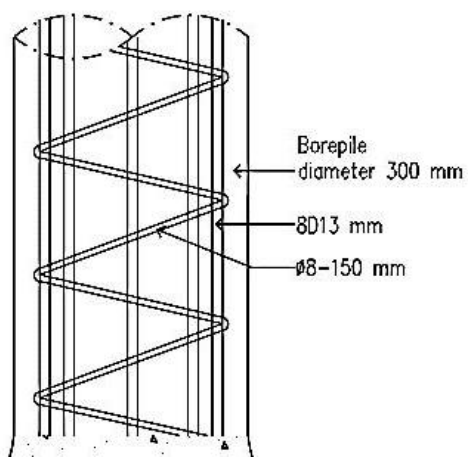

Gambar 4. Spiral pada Segmen Bored Pile (Sumber: Anonim, 2018)

2. Sebelum memasukkan rangkaian besi bored pile di masukkan casing yang berfungsi untuk menahan dinding tanah agar tidak longsor dan tidak menutupi lubang bored pile. 
3. Proses pemasangan besi tulangan yang sudah dirakit ke dalam lubang tiang bor vertikal. Pada tahap pemasangan rangkaian besi yang sudah di rakit menggunakan mesin minicrane untuk memudahkan memasukkan rangkaian.

\subsubsection{Metode pengerjaan pengecoran bored pile}

Volume pekerjaan adalah $74.394 \mathrm{~m}^{3}$, dengan durasi selama 11 hari. Komposisi sumber daya pekerjaan pengecoran bored pile dapat dilihat pada tabel di bawah ini:

Tabel 4. Komposisi Sumber Daya Pekerjaan Pengecoran Bored Pile

\begin{tabular}{ccc}
\hline Tenaga kerja & Alat & Bahan \\
\hline 10 or.pekerja & 1 unit & $74.394 \mathrm{~m}^{3}$ \\
1 or.mandor & concrete & beton ready \\
1 or.kepala & $\begin{array}{c}\text { mixer truck } \\
\text { tukang }\end{array}$ & $\begin{array}{c}\text { mix } \\
\text { unit pipa }\end{array}$ \\
3 or.tukang & $\begin{array}{c}\text { tremie } \\
\text { batu }\end{array}$ & 1 unit \\
& concrete & \\
& bucket & \\
\hline
\end{tabular}

Pekerjaan pengecoran dilakukan dengan menggunakan tremie pipe yang panjangnya mencapai dasar lubang bor, sehingga menjamin kontinuitas pengecoran beton. Sebelum dilakukan pengecoran, tremie pipe harus menyentuh dasar lubang bor. Setelah tremie pipe menyentuh dasar lubang bor, pemasangan concrete bucket diatas pipa tremie yang menjadi kesatuan dengan pipa tremie. Setelah itu baru dilakukan pengecoran menggunakan beton K-250 dengan beton ready mix. Slump beton digunakan $10 \mathrm{~cm}-12.5 \mathrm{~cm}$ agar diperoleh beton yang mudah mengalir melalui tremie pipe. Pengecoran dilakukan sampai dasar tanah.

Setelah pipa tremi dipasang ditengah tulangan besi, kemudian adukan cor dimasukan ke tremi secara terus menerus, disaat bersamaan pipa tremi bergerak naik turun perlahan sehingga lumpur terdorong keluar melalui pipa tremi.

Berikutnya untuk memastikan lubang bor terisi beton bersih maka harus dipastikan beton kotor keluar seluruhnya dari lubang.

\subsection{Pekerjaan Pile Cap}

Volume pekerjaan adalah 136.708 $\mathrm{m}^{3}$, dengan durasi selama 6 hari. Komposisi sumber daya pekerjaan pile cap dapat dilihat pada tabel di bawah ini:

Tabel 5. Komposisi Sumber Daya Pekerjaan Pile Cap

\begin{tabular}{ccc}
\hline Tenaga kerja & Alat & Bahan \\
\hline 15 or.pekerja & 1 unit & 2 bh.cat \\
1 or.mandor & waterpass & pilox \\
1 or.surveyor & 1 bh.meteran & 225 bh. \\
& 6 cangkul & batako \\
& dan sekop & \\
\hline
\end{tabular}

Setelah proses pengecoran bored pile bagian bawah selesai dilanjutkan dengan pekerjaan pile cap. Hal tersebut bertujuan untuk membuat tiang-tiang bekerja sebagai 
satu kesatuan dalam menahan beban dari struktur atas, baik itu vertikal, lateral maupun gulingan. Semua bahan yang digunakan untuk pekerjaan ini harus memenuhi ketentuan-ketentuan yang berlaku. Adapun langkah-langkah pekerjaan untuk pile cap adalah sebagai berikut:

\subsubsection{Pekerjaan persiapan}

1. Pekerjaan pile cap diawali dengan pekerjaan persiapan, yaitu menentukan as pile cap dan penandaan posisi bekisting yang akan dipasang menggunakan theodolit dan waterpass.

2. Pekerjaan galian, metode untuk pekerjaan penggalian dengan menggunakan tenaga manual dengan menggunakan alat cangkul.

3. Sisakan tulangan pile sebagai stek pondasi untuk penyambungan kolom dengan pile cap. Pemboran hanya sampai elevasi dasar pile cap saja.

\subsubsection{Pekerjaaan lantai kerja pile cap}

Volume pekerjaan adalah 136.708 $\mathrm{m}^{3}$, dengan durasi selama 6 hari. Komposisi sumber daya pekerjaan lantai kerja pile cap adalah:
Tabel 6. Komposisi Sumber Daya

Pekerjaan Lantai Kerja Pile Cap

\begin{tabular}{ccc}
\hline Tenaga kerja & Alat & Bahan \\
\hline 15 or.pekerja & 1 unit & $0.675 \mathrm{~m}^{3}$ \\
1 or.mandor & concrete & pasir \\
& mixer truck & $430.740 \mathrm{~kg}$ \\
& 1 unit & semen \\
& concrete & air \\
& vibrator & \\
\hline
\end{tabular}

Pekerjaan pembuatan lantai kerja menggunakan beton non struktur dengan menimbun pasir urug setebal $100 \mathrm{~mm}$ dan beton setebal $100 \mathrm{~mm}$, seperti Gambar 5 .

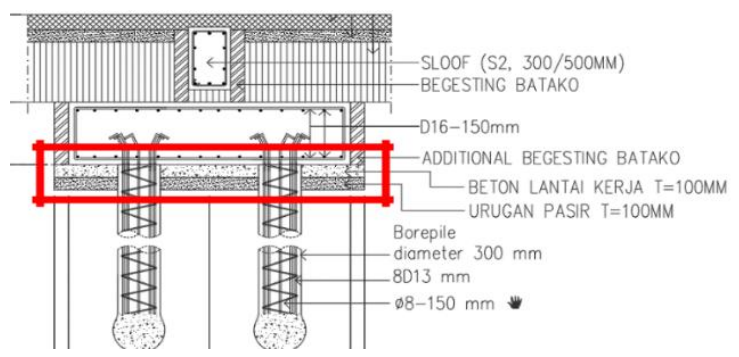

Gambar 5. Lantai Kerja Pile Cap (Sumber: Anonim, 2018)

\subsubsection{Pekerjaaan bekisting pile cap}

Volume pekerjaan adalah 237.474 $\mathrm{m}^{2}$, dengan durasi selama 14 hari. Komposisi sumber daya pekerjaan bekisting pile cap dapat dilihat pada tabel di bawah ini:

\section{Tabel 7. Komposisi Sumber Daya} Pekerjaan Bekisting Pile Cap

\begin{tabular}{ccc}
\hline Tenaga kerja & Alat & Bahan \\
\hline 25 or.pekerja & 1 unit & $225 \mathrm{bh}$. \\
2 or.mandor & waterpass, & batako \\
15 or.tukang & palu, cetok, & $0.096 \mathrm{~m}^{3}$ \\
batu & ember & pasir \\
2 or.kepala & & $410.124 \mathrm{~kg}$ \\
tukang & & semen \\
& & air \\
\hline
\end{tabular}


Setelah pekerjaan lantai selesai dilaksanakan maka, tahap selanjutnya memasang bekisting untuk pile cap. Bekisting dibuat dengan batako, karena batako cukup kuat untuk menahan beban sebagai bekisting serta cukup murah dan tidak perlu lagi melepas bekisting ketika beton sudah kering untuk pada akhirnya ditimbun bersama saat pengecoran. Adapun langkah-langkah pekerjaan bekisting untuk pile cap adalah:

1. Mengadakan pengukuran dan penandaan/marking posisi bekisting yang akan dipasang dimana untuk tiap-tiap pile cap.

2. Bekisting dirakit sesuai dengan ukuran pile cap masing-masing, dimana digunakan menggunakan batako $30 \mathrm{~cm} \mathrm{x} 15 \mathrm{~cm}$ x $10 \mathrm{~cm}$.

\subsubsection{Pekerjaan pembesian pile cap}

Volume pekerjaan adalah 5454.21 $\mathrm{kg}$, dengan durasi selama 9 hari. Komposisi sumber daya pekerjaan pembesian pile cap adalah:

Tabel 8. Komposisi Sumber Daya Pekerjaan Pembesian Pile Cap

\begin{tabular}{ccc}
\hline Tenaga kerja & Alat & Bahan \\
\hline 20 or.pekerja & 1 unit mesin & $5454.21 \mathrm{~kg}$ \\
2 or.mandor & cutting bar & besi \\
20 or.tukang & 1 unit & $770 \mathrm{~kg}$ \\
batu & penggulung & kawat \\
2 or.kepala & besi & bendrat \\
tukang & 1 unit \\
& waterpass \\
& 1 bh.meteran \\
\hline
\end{tabular}

Sebelum pekerjaan pengecoran harus membuat/merakit tulangan pile cap dan juga merakit tulangan kolom yang akan di pasang bersamaan dengan tulangan pile cap. Metode saat perakitan tulangan baja (pembesian) dipilih dengan metode konvesional dan berdasarkan gambar perencanaan sebagai berikut:

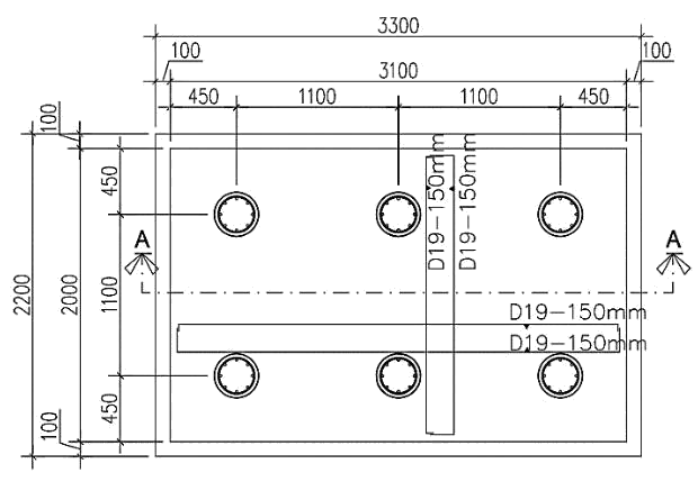

Gambar 6. Tulangan Pile Cap BP1 (Sumber: Anonim, 2018)

Adapun langkah-langkah pekerjaan pembesian pile cap yaitu sebagai berikut:

1. Memotong besi-besi sesuai dengan ukuran serta syaratsyarat pembengkokan dan penjangkaran.

2. Setelah selesai dipotong, tahap selanjutnya adalah perakitan pembesian pile cap.

\subsubsection{Pekerjaan pengecoran pile cap \\ Volume pekerjaan adalah 117.632 $\mathrm{m}^{3}$, dengan durasi selama 14 hari. Komposisi sumber daya pekerjaan pengecoran pile cap adalah:}


Tabel 9. Komposisi Sumber Daya

Pekerjaan Pengecoran Pile Cap

\begin{tabular}{ccc}
\hline Tenaga kerja & Alat & Bahan \\
\hline 25 or.pekerja & 1 unit & $117.632 \mathrm{~m}^{3}$ \\
1 or.mandor & concrete & beton ready \\
5 or.tukang & mixer truck & mix \\
batu & 1 unit & \\
1 or.kepala & $\begin{array}{c}\text { concrete } \\
\text { vibrator } \\
\text { tukang }\end{array}$ & \\
& ember & \\
\hline
\end{tabular}

Untuk pengecoran pile cap dalam proyek ini menggunakan tenaga manual dengan menggunakan alat concrete mixer sesuai dengan rencana. Sebelum dimulainya pengecoran pile cap, terlebih dahulu dibersihkan di lokasi pengecoran, kemudian membuat batas pengecoran pile cap dan agar beton dapat masuk kedalam tulangan pile cap maka digunakan alat vibrator untuk meratakan serta ditekan dengan tekanan tinggi agar beton dapat memadat dan terakhir menghentikan pengecoran serta meratakan atau menghaluskan permukaan beton.

\section{SIMPULAN DAN SARAN}

\subsection{Simpulan}

Berdasarkan hasil kajian yang dilakukan, dapat disimpulkan sebagai berikut:

1. Pekerjaan bored pile:

a. Pekerjaan persiapan diawali dengan penentuan titik pusat pile dan penempatan alat bored pile. b. Pekerjaan pengeboran menggunakan metode wet drilling, volume $1105.00 \mathrm{~m}$ dengan durasi 8 hari.

c. Pekerjaan pembesian meliputi proses fabrikasi dan pemasangan tulangan ke dalam lubang bor dengan volume $9309.61 \mathrm{~kg} \quad$ dan durasi 13 hari.

d. Pekerjaan pengecoran dilakukan menggunakan pipa tremi, volume $74.394 \mathrm{~m}^{3}$ dengan durasi 11 hari.

2. Pekerjaan pile cap:

a. Pekerjaan persiapan adalah penentuan as pile cap dan pekerjaan galian.

b. Pekerjaan lantai pile cap dengan pasir urug dan beton dengan volume $136.708 \mathrm{~m}^{3}$ selama 6 hari.

c. Pekerjaan bekisting dengan menggunakan batako dengan volume $237.474 \quad \mathrm{~m}^{2}$ dikerjakan selama 14 hari.

d. Pekerjaan pembesian terdiri dari pekerjaan pembentukan tulangan dan perakitan tulangan, dengan volume $5454.21 \mathrm{~kg}$ dengan durasi 9 hari. 
e. Pekerjaan pengecoran dilakukan dengan metode manual, volume $117.632 \mathrm{~m}^{3}$ dengan durasi 14 hari.

\subsection{Saran}

Dalam tahap perencanaan pelaksanakan suatu kegiatan proyek hendaknya menerapkan strategi terhadap metode yang terpilih agar senantiasa mempertimbangkan efisensi dan efektipitas dari segi waktu, mutu biaya dan sehingga tujuan proyek tercapai sesuai harapan. Perlu dilakukan kajian lebih lanjut pada kegiatan pekerjaan lainnya.

\section{DAFTAR PUSTAKA}

Anonim. (2018). Penyusunan DED Pembangunan GOR Tenis Meja di Kecamatan Abiansemal. Mangupura.

Asiyanto. (2010). Manajemen Produksi untuk Jasa Konstruksi. Jakarta: PT. Pradnya Paramita.

Dhiva, I. G. N. A. (2014). Analisis Produktivitas Pengeboran Pondasi Bor Pile Dengan Menggunakan Mesin Bor Ringan. Jurnal Rekayasa Sipil, 8(2), 128-135.

Dipohusodo, I. (1996). Manajemen Proyek dan Konstruksi (Jilid $1 \quad \&$ ). Yogyakarta: Kanisius.

Ervianto, W. I. (2005). Manajemen Proyek Konstruksi. Yogyakarta: Andi Offset.

Fadilah, U. N., \& Tunafiah, H. (2018). Analisa Daya Dukung Pondasi Bored Pile Berdasarkan Data N-SPT Menurut Rumus Reese\&Wright Dan
Penurunan. Jurnal IKRA-ITH Teknologi, 2(3), 7-13.

Hardiyatmo, H. C. (2011). Analisis dan Perencanaan Fondasi I (Edisi 2). Yogyakarta: Gadjah Mada University Press.

Jawat, I. W., Rahadiani, A. A. D., \& Armaeni, N. K. (2018). Produktivitas Truck Concrete Pump Dan Truck Mixer Pada Pekerjaan Pengecoran. PADURAKSA, 7(2), 164-183.

Livia, \& Suhendra, A. (2018). Studi kapasitas tiang bor berdasarkan metode pile driving analyzer (PDA) dan load cell. JMTS: Jurnal Mitra Teknik Sipil, $1(1), \quad 82$. https://doi.org/10.24912/jmts.v1i1.22 45

Mubarak, Bulba, A. T., \& Yunita, M. (2014). Studi nilai produktivitas pekerjaan pondasi bored pile. Jurnal Teknik Sipil Universitas Syiah Kuala, 3(2), 199-208. Retrieved from

http://jurnal.unsyiah.ac.id/JTS/article /view/5584/4615

Syah, M. S. (2004). Manajemen Proyek Kiat Sukses Mengelola Proyek. Jakarta: Gramedia Pustaka Utama.

W.Lar, C. F. (2006). Project Management: The Managerial Process 3th Edition. The McGraw - Hill Companies, Inc. 